\title{
THE IMPACT AND EFFECTS OF TRAUMA RESULTING FROM EXCOMMUNICATION
}

Authors:

Mpiyakhe J. Kubeka ${ }^{1}$

Maake J. Masango ${ }^{1}$

\begin{abstract}
Affiliations:
${ }^{1}$ Department of Practical

Theology, University of

Pretoria, South Africa
\end{abstract}

Correspondence to:

Maake Masango

email:

maake.masango@up.ac.za

Postal address:

PO Box 84173, Greenside

2034, South Africa

\section{Keywords:}

trauma; effects; impact;

pain; stories

\section{Dates:}

Received: 17 Feb. 2010

Accepted: 29 May 2010

Published: 11 Oct. 2010

How to cite this article:

Kubeka, M.J. \& Masango,

M.J., 2010, 'The impact and

effects of trauma resulting

from excommunication',

HTS Teologiese Studies/

Theological Studies (66)1,

Art. \#803, 13 pages. DOI:

10.4102/hts.v66i1.803

\section{This article is available}

at:

http://www.hts.org.za
(C) 2010. The Authors.

Licensee: OpenJournals Publishing. This work is licensed under the Creative Commons Attribution License.

\section{ABSTRACT}

This article will attempt to critically analyse various aspects of the state of trauma. It will analyse the impact, consequences and effects of trauma resultant from excommunication of clergy and how the practice has been handed down through the ages. The ultimate aim of the authors is an understanding of how excommunication evolved throughout the ages and the nature of its impact on the victims or survivors thereof. The author's own first-hand encounter prompted him to research this subject. It is imperative to look at the scientific application of the ritual as it affects all the stakeholders and participants, active or passive.

An overview of various biblical eras will be given, including the Old Testament prophets, Christ's own views as well as the period of St Paul in the New Testament.

\section{INTRODUCTION}

A distinct period in church history will be analysed, namely the Reformation period. Martin Luther will be the key person focussed on. An analysis of Luther's own response and reaction to excommunication will be given. Excommunication leaves the victims or survivors thereof with indelible scars and marks, often of an unbearable nature. It is for this reason that the author would cite the practical experiences of excommunication of three victims/survivors. Since this is an age-old church practice, it is viewed in this article from the perspective of the younger Luther, who was himself a subject of the same humiliating experience. Martin Luther is considered as one of the most uncompromising reformers of all times:

In the present century much Luther scholarship has followed Holl in concentration upon the younger Luther. The presupposition appears to be that the creativity, vigour and distinctiveness of Luther's contribution to theology must be sought in these early years.

(Trigg 1994:3)

'Thus those preachers of indulgences are in error who say that, by indulgences of the Pope, a man is loosed and saved from all punishment' (Hyma 1928:37).

The foregoing authorities provide a base that prompted the author to choose as a historic reference the person of Martin Luther. Hyma (1928:70) quotes the following about Martin Luther: 'Believe me; I am exposed in this quiet hermitage to a thousand devils incarnate, than against the "spirits of wickedness, dwelling in high places"' (Ephesians VI:12).

Luther stands therefore both as a model of and uncompromising contributor to the theology that was later to usher in a new historic era.

This vigorous approach that led to the transformation of various church practices and rituals is more imperative now than in Luther's time, an opinion upheld by the author who is backed up by Gerkin (1997):

It is little wonder that the field of pastoral care is in a time of transition and controversy. How to sort out all of the diversity within theology and make use of it in setting new directions for pastoral care practice becomes an interesting but difficult problem.

(Gerkin 1997:105)

\section{DEFINITION OF TRAUMA}

Webster's New World Dictionary defines trauma as 'an emotional shock, often having a lasting psychic effect' (Guralnic 1973:607).

It is evident from the foregoing definition that trauma is a deep-rooted and deep-seated long-lasting pain. The pain is drawn as having devastating effects that result from shock.

The notion of the wound defined by Guralnic (1973) is bolstered by Mills (2007), writing on the subject of alterity, pain and suffering:

At the centre of atrocious pain is the tension between what can be conceived and what is. It is when domination and terror become absolutes...that we cannot discover in ourselves a possible scenario to explain what happened. We want to say, it is inconceivable, yet we know it was conceived. The likely response to such tension is to reconcile the balance on the side of 'usual' meaning.

(Mills 2007:148)

The results of trauma as portrayed by Mills (2007) manifest themselves not only in illusions but also in misconceptions about the actual and factual realities. 
The state of shock, the depth of the wound and the gruesome brutality of the shock are further portrayed by Mills (2007) as follows:

Atrocious pain is an embodiment of space in which pain passes beyond any normal borders, both materially and metaphorically. Like Absurd pain it calls on the reader to stay still, to be in that space of uncontrollable violence and loss, to let it grow fully, outside of giving it a good/bad profile.

(Mills 2007:149)

The author views both opinions as pivotal in the understanding of trauma in both religious and secular circles. He therefore agrees that trauma is actually both the embodiment and personification of the incurred pain. The ethos of such a pain will be understood, internalised and interpreted differently by different people.

This means that people differ in degrees of absorption of pain There is an age-old adage in Sesotho (one of the 11 official languages of South Africa) that says, 'Bohloko baseeta bo utlwiwa ke monga sona'. An equivalent English translation would state, 'The best interpreter of the pain is the recipient thereof.' The inference here is that the best person to relate to the pain is the one who had the first-hand encounter with the plight, whatever its nature.

It is important at this stage to introduce the subject of excommunication and seek to understand its implications primarily within the religious context because the subject is of vital importance in church circles. This subject appears to be an abstract quagmire that has caused more harm than good in church or religious circles. If the message of the Gospel is to be presented with the care and sensitivity inherent in the reconciliatory intention of He who created humanity in His own image, what Gerkin (1997:57) says should be taken into account 'We schematized pastoral care as a quadrilateral structure involving care of the tradition, care of the culture, care of the individual, and care of the gathered community of Christians.'

Any practice and behaviour contrary to the foregoing proposition by Gerkin will suggest that the adherents of the faith are mere confessors rather than practitioners thereof. This tendency immediately qualifies the definition of excommunication provided by Guralnik (1973:204): '...to exclude from the communion with a church'.

Within the community of faith there should be an element of inclusion, even with regard to the offender, so that the community would be seen as not excluding or discriminating against any of its members. The author agrees with this proposition of inclusion by Guralnic (1973).

He further agrees with Gerkin (1997) that pastoral care should be holistic. Moreover, it should provide a multifaceted quadrilateral and accommodative environment characterised by care and a reciprocally beneficial atmosphere of safety where no member will feel threatened.

\section{The traditional Old Testament view of excommunication upheld by the law}

The Law of Moses propagated corrective action, which took various forms such as being set in isolation:

But if the bright spot is white on the skin of his body, and does not appear to be deeper than the skin, and its hair has not turned white, then the priest shall isolate the one who has the sore seven days.

Now if the leper on whom the sore is, his clothes shall be torn and his head bare; and he shall cover his moustache, and cry, 'Unclean! Unclean!' He shall be unclean. All the days he has the sore he shall be unclean. He is unclean, and he shall dwell alone; his dwelling shall be outside the camp.

(Lv 13:45)
Both scriptures indicate that the fair portion of the 'unclean' person is a place somewhere on the outskirts of the city. The author sees the legalistic practice of the Old Testament regarding isolation and excommunication not as having destructive effects but rather as having a redemptive overall intention.

Israel as a nation suffered a great deal of rejection, the kind that can be equated with excommunication itself, as portrayed by Pieterse (2004):

The Old and New Testament show that God champions and cares for the poor people in a very special way. When Israel was an insignificant, enslaved nation in Egypt, subject to oppression and poverty, God revealed Himself to Moses with these words: 'The cry of the people of Israel has come to Me, and I have seen the oppression with which the Egyptians oppress them.

(Pieterse 2004:82)

\section{The prophets}

The prophets were adherents of the law and as such believed in the full might thereof. Hezekiah said, 'What shall be the sign that I shall go up to the house of the Lord?' (Is 38:22).

This scripture indicates that leprosy, a symbol of uncleanness, was treated through being denied access to the house of God and being cast out of the community.

\section{The New Testament view of excommunication upheld by Jesus Christ}

Jesus indicates that excommunication should be the last resort when all other avenues of corrective action are exhausted and the offender blatantly and deliberately refuses to repent:

And if he refuses to hear them, tell it to the church. But if he refuses even to hear the church, let him be to you like a heathen and a tax collector.

(Mt 18:17)

\section{The early church}

In the early church, Paul had this to say about the practice of excommunication:

In the name of our Lord Jesus Christ, deliver such a one to Satan for the destruction of the flesh that his spirit may be saved in the day of the Lord Jesus.

(1 Cor 5:4-5)

\section{The Afro-centric view of excommunication}

The journey of Jesus with his Church is evidently one of encouragement, guidance and correction in its daily activities. It is his pastoral care for those who believe in his name.

(Waruta \& Kinoti 2005:219)

Contrary to the notion of isolation suggested by the definition of excommunication provided by Guralnic (1973) above, the author agrees with the concept of a bond and communal life advocated by Magesa (quoted in Waruta \& Kinoti 2005:221) to the effect that '... this community translates necessarily into practical actions of affectivity in the form of active love'.

Throughout the entire Bible, as observed in the above references, excommunicating an individual is an explicit redemptive endeavour. The author agrees in no uncertain terms that the offender should be excommunicated with the overall objective of redemption, as suggested by the Old and New Testament writings.

The author further agrees with the Afro-centric redemptive emphasis espoused by Waruta and Kinoti (2005), as cited above. $\mathrm{He}$ aligns himself with the therapeutic and reconciliatory approaches proposed by Scripture and supported by Waruta and Kinoti, inasmuch as such a rite intends to bring one to ultimate wholeness. 


\section{EFFECTS OF TRAUMA}

As a result of excommunication, one will suffer trauma that will manifest itself in various forms. This traumatic encounter will leave one with terrible scars and effects; regarding which J.L. Herman (1997) say the following:

Atrocities, however, refuse to be buried. Equally as powerful as the desire to deny atrocities is the conviction that denial does not work. Folk wisdom is filled with ghosts who refuse to rest in their graves until their stories are told.

(J.L. Herman 1997:1)

As a result of the traumatic experiences, people reflect what Patton (1990:14) portrays in the following way: 'Many people have a limited ability to share what has happened to them in their lives.'

He further states, 'If persons are genuinely to experience their human being, they need to reflect on, re-create, and share what has happened to them' (Patton 1990:15).

It is important to note that the practice of bottling up emotions is a breeding ground for trauma, as attested by Freud (1939) in the following way:

The effects of the trauma are twofold, positive and negative. The former are endeavours to revive the trauma, to remember the forgotten experience, or, better still, to make it real - to live once more through a repetition of it.

(Freud 1939:122)

Sipe and Rowe (1984:153) argue as follows: 'One must be cautious when forecasting the long-term results of trauma or of a deprived environment. The effects may not appear for many years.'

The author agrees with the above three propositions inasmuch as it is in venting one's hurts that one will be able to combat the brutal effects of trauma.

The effects of trauma need to be considered within the scope of an empathic understanding, regarding which Neethling (2002) states the following:

Empathy on the other hand is something completely different. It is the ability to see and experience things from the perspective of another, and consequently we do not only understand how others feel, we share those feelings, we also feel for them with our very being.

(Neethling 2002:23)

The author agrees with Neethling (2002) that it is important not only to understand how others feel but also to share in those feelings. This is the identification pointed out by Sipe and Rowe (1984) in their indication that the effects of trauma may not appear for many years, hence the need to identify fully with those who are going through traumatic encounters.

\section{Kinds of trauma}

Various kinds of trauma result from excommunication. Drawing from the life of Paul, Freud (1939) highlights the following:

Paul, a Roman Jew from Tarsus, seized upon this feeling of guilt and correctly traced it back to its primaeval source. This he called original sin; it was a crime against God that could be expiated only through death.

(Freud 1939:139)

A single trauma does not usually produce permanent damage. When a single trauma appears to produce permanent damage, it is usually found that other factors are present, such as separation, as during the trauma of hospitalization, or the manner in which the trauma was handled, for example, an absence, of emotional support.

(Sipe \& Rowe 1984:153)

Trauma causes indelible damage, the impact of which may become clear later in life, as indicated by Sipe and Rowe (1984) above. In Paul's life, as proposed by Freud (1939), there was a sense of guilt traceable to the primaeval source. In this regard, the author quotes the words of Estardt (1983):

One of the personal factors that impact the outcome of a crisis is past experience: Does this situation evoke an unsuccessfully resolved crisis in a person's life? To the extent that a person is relying on defence mechanisms that are maladaptive, there is the likelihood that a stressor in such a case will evoke longer-lasting disorganization.

(Estardt 1983:142)

It is worth noting that trauma resulting from isolation is as old as humanity. During His earthly ministry, Christ dwelt among a people traumatised by the class-stratified system, of which Wimberly (1999) says the following:

In this class-stratified system, a person's worth was value-laden, based on honour and shame. There were those who were considered highly valued, and there were those who were not. Those who were deemed unworthy were the marginalized and disenfranchised.

(Wimberly 1999:23)

The situation has not altered from the time of Christ's earthly ministry. The author is of the opinion that if the situation has changed in terms of classification and preferential treatment of people today as compared to Christ's time, it has changed rather for the worst.

\section{Stress resulting from trauma}

The stress resulting from a traumatic encounter cannot be overlooked, hence this opinion by Estardt (1983):

Studies about stress show that expectation is an important factor in how a person will experience stress. Stress is often the disappointment ratio of the difference between the expectation and the reality.

(Estardt 1983:149)

In the faith community, one would anticipate some form of system that can address issues in a Christocentric manner, notwithstanding the fact that wherever there are people, there exists a likelihood of differences in many aspects of life. It is for this reason that everybody in such a community holds some form of hope of protection by the institution that advocates the values Christ espoused on the very cross where He was crucified.

Failure by the faith community to meet the expectations of the members results in the following, according to Oden (2007):

This has spawned a dilemma of self-esteem. The oral traditions of African traditional religion have seemed to have less value or authority than written texts. The comparison of orality to textuality always seems tilted and unfair. The cultural and intellectual richness of native African religion is wrongly thought to be largely primal and oral. So it imagines itself as burdened with a desperate disadvantage in relation to written traditions. This is not a fair playing field.

(Oden 2007:270)

In support of the foregoing arguments, the author strongly believes that as a result of a people who have become a law unto themselves, who can hire and fire willy-nilly, the faith has become subject to scrutiny and even the authority of procedures and disciplinary processes and mechanisms employed to execute discipline can be questioned.

It is because of this failure to meet the Christ-like virtues and expectations addressed by Estardt (1983) above that processes qualify to be seen as only traditional, in the words of Oden (2007). Stress is bound to occur as a result of rejection since human beings are by nature creatures that wish to belong, which Browning (1996:169) portrays as follows: 'Humans have social needs to belong to, cooperate with, and sustain the groups to which they belong.'

\section{Behavioural patterns or characteristics resulting from} excommunication

There are distinct characteristics as well as behavioural patterns that will be observed in a person who was excommunicated. 
In the light of the definition of excommunication, it becomes evident that such characteristics or traits are both irresistible and inevitable.

The superego is not only the giver of laws; it is the source of selfsatisfaction and self-esteem, the supplier of necessary elements of narcissism, elements which replace in part the praise and devotion of parents. To be loved and approved by one's superego becomes as important as being loved and approved by parents and other important people in one's life.

(Sipe \& Rowe 1984:158)

The author agrees with the proposition by Sipe and Rowe (1984) that the knowledge of being loved and cherished is extremely therapeutic. He further believes that annihilation of the sense of being and degradation of one's esteem will result when one has been subjected to the torture and torment of rituals such as excommunication. This notion is supported by Wimberly (1999:11) who discusses it with emphasis on the process of forgiveness: 'To forgive prematurely, I emphasized, could lead us back into relationships that increase our shame and feelings of self-degradation.'

The natural tendency for one who feels rejected is to align him or her with deviant conduct so as to create a defence mechanism. The victim or survivor tends to show extremes of uncalled-for behaviour. This picture is painted well by Wimberly (1999) in one of his interviews:

Drugs and alcohol made me more sociable and less shy. I needed those substances to feel secure when I was around others. I always wanted to be popular and outgoing, and the drugs and alcohol allowed me to be more outgoing.

(Wimberly 1999:107)

The ultimate shame, and one from which it is almost impossible to recover, is the feeling that one is unloved by God. The root of shame, according to Leon Wurmser,

... is believing that one is unlovable and will never be loved. If such a humiliating conclusion is true from God's perspective, then there is no ground for hope at all.

(Wimberly 1999:51)

The above process affects clergy who are excommunicated unjustly in the Pentecostal Church. Since the author is the survivor of a similar plight, he can deeply identify with this hopelessness, which has created a deep hunger to consider including a chapter on the subject of being excommunicated by God in his PhD work. He unequivocally identifies with the state of shame Wimberly addresses. He understands and feels the deep-seated pain articulated by Wimberly in his conversations on Job. There is, however, an immediate solution that Wimberly (2003) proposes:

For example, some conversations are self-esteem building and others are not. If we encounter negative conversations over and over again, they tend to have a pejorative impact on how we feel about ourselves. Negative conversations produce negative evaluations of ourselves.

(Wimberly 2003:17)

The author agrees that the most helpful way out of the frustrations presented by the effects of trauma, which ultimately lead to a sense of worthlessness will be the solution proposed by Pollard (1997), who is an advocate of positive deconstruction It is in the state of self-acceptance, the desire to break out of the prison of self-pity and the courage to soar through the limitless skies that we can find our healing:

The process is called 'deconstruction' because I am helping people to deconstruct (that is, take apart) what they believe in order to look carefully at the belief and analyse it. The process is positive because this deconstruction is done in a positive way-in order to replace it with something better.

(Pollard 1997:44)

\section{EXCOMMUNICATION DURING THE REFORMATION}

The theology of the church reached an inflection point during the Reformation era. Martin Luther in particular informed the church anew of many fallacious practices that were adopted foreign heresies. He addressed the authorities and implied that they were drinking impure water and called them to return to the source of the Divine Word: 'You ask to be permitted to hear the Gospel in liberty. Can't you change your residence and come here to drink at the source of Divine Word?' (Hyma 1928:75).

According to Yule (1985:58), Luther was emphatic about the Gospel that sees Christ in others. He actually went to the extent of advising about the dethronement of a certain people:

My brethren, (sic) the peasants, the princes who oppose the propagation of the Gospel light among you are deserving of God's vengeance; they merit dethronement. But would you not be also guilty, were you to stain your hands and souls with the blood which you intend to shed?

(Hyma 1928:75)

The author would like to reinforce the stated opinions by pointing out that though Luther was a victim of the ritual of excommunication himself, he also advocated for the same, as pointed out by the notion of dethronement he addressed, as noted above.

This argument leads us to the next level of spelling out some of the reasons that could lead one to being excommunicated. The study therefore intends to examine the measure of justice, truth, honesty and love when excommunication is practised, with the ultimate aim of not only restoring the victim or survivor but also of fully bringing him or her to appreciate the ritual as a necessary act of chastisement. From the early writings of theologians such as Luther it emerges that excommunication had always been used as a process of discipline by the church against a few.

\section{Allen (1974) states the following:}

Thus, excommunication was being used to enforce the political aims of the papacy, and it was also being used to enforce economic aims of various branches of the church. For example, it was used to force the timely payment of tithes, annates, or other ecclesiastical debts, and to force town councils to stop taxing religious bodies, which were selling beer, wine, fabrics, etc.

(Allen 1974:35)

The author disagrees with the manner in which excommunication was exercised and sees this practice as an unbiblical imposition of power on defenceless subjects and people who were meant to be rather recipients of the Gospel of grace. This shows that the ritual was not based on the Word of God or even exercised as Christ Himself would have done. This is apparently the spirit that was handed down the ecclesiastical generations.

\section{Excommunication as a result of pursuing a questionable doctrine}

According to Hyma (1928),

There was a time when the faith had no need of defenders; it had no enemies. Now it has one who exceeds in malignity all his predecessors, who is instigated by the devil, who covers himself with the shield of charity, and, full of hatred and wrath, discharges his viperish venom against the Church and Catholicism.... What similar pestilence has ever attacked the Lord's flock?

(Hyma 1928:73)

Against the practice of his day, Luther is stated to have reasoned as follows:

In the first part of the treatise, Luther argues that everything derives from faith. If a man (sic) has faith, he has everything; if a man has no faith, nothing else suffices him.

(Atkinson 1983:102) 
Those in authority had seen a new and threatening theology introduced by one they called the enemy of the faith, who nevertheless derived his theology from his focus on Christ:

Faith, once it ceases to be completely other-directed (Christdirected), becomes a self-conscious and self reliant human piety, in other words, a work. Properly understood, however, faith 'is a constant gaze that looks at nothing except Christ'.

(Trigg 1994:90)

The author sees two bodies at loggerheads with each other: the authorities who had a vested interest in the status quo and Martin Luther who was an advocate of 'new theology', as it was interpreted. In this respect he agrees with Gerkin (1997:145) who strongly believes, 'Each community, with its unique story and its unique values, vies for the fidelity of its members.'

It was in this era that Martin Luther emerged to challenge the heretical teachings that were prevalent and vehemently perpetuated by the church, to the detriment of the innocent and ignorant.

\section{Martin Luther's attitude}

'Suffering is unavoidable, but the proper understanding of it, and an ability to welcome and use it spiritually, was the acid test of sincerity and true godliness' (Yule 1985:52).

It is two years since I published a small book, entitled The Captivity of the Church in Babylon. It has annoyed the Papists, who spared neither falsehoods nor abuse against me. I willingly forgive them.

(Hyma 1928:74)

The author draws a lesson from the life and character of Luther. He is reminded of the time he took his own 'saga' to the press and can only wish that he had learnt the therapeutic mode applied by Luther, namely that of willingly forgiving one's persecutors. He further agrees that though suffering is inevitable, there is a bigger cause to stand for, which the Lord Jesus taught His followers, as applicable now as it was during His earthly ministry: 'And forgive us our debts, as we forgive our debtors' (Mt 6:12)

It is this therapeutic attitude that carried Luther amidst his trials, attested to by A.E.S Wimberly (2004) as follows:

Just as nurturing faith and hope in the Holy Spirit is not a matter of presenting propositions, so also nurture is not simply a matter of the leading of the mind. Nurture is a matter of engaging our whole selves-of enkindling our minds, emotions, and behaviours to the end that we truly see, move, and have our being in life in response to God's Spirit.

(A.E.S Wimberly 2004:58)

Martin Luther was fully aware of the extent and impact of the truth inherent in the foregoing reasoning by A.E.S Wimberly (2004). He had personally discovered the truth the author applauds as both credible and sacred:

For I have not found in Latin or German a more wholesome theology or one more constant with the Gospel. Taste, therefore, and see how sweet is the Lord, where formerly you have seen how bitter everything in us is.

(Hyma 1928:32)

Luther challenged, fought and confronted the ills of his day and forged a new way, leaving behind him trails of integrity that would immortalise him throughout all history. Yet he maintained a very humble and sober attitude in his state of rejection and excommunication:

Luther claimed to have created no new theology.... I beg that my name be passed over in silence, and that people call themselves not Lutheran, but Christians. What is Luther? My teaching is not mine. Saint Paul did not want Christians to be called Paulinians, but Christians (1 Cor 3).

(Hyma 1928:70)

Only when the fullness of divine mystery is experienced can one speak, like Luther, in a way that does not seek self-glory but that acknowledges the truth:

Let this mind be in you which was also in Christ Jesus, who being in the form of God, did not consider it robbery to be equal with God, but made Himself of no reputation, taking the form of a bondservant, and coming in the likeness of men. And being found in appearance as a man, He humbled Himself and became obedient to the point of death, even the death of the cross.

(Phlp 2:5-8)

As was the case with Christ, labelling as a form of humiliation and psychological torture did not change Luther, according to Nestingen (1982):

One of the nicknames given to Luther and his early compatriots, besides the originally taunt 'Lutheran', was the 'sola-ists.' The latter word, which comes from the Latin word for 'only', was intended partly as a barb. It was aimed at the Lutheran love for exclusive sayings, such as the word alone - grace alone, and faith alone.

(Nestingen 1982:27)

The author notes with appreciation the uncompromising spirit and courage of Luther, as further emphasised by Nestingen (1982):

Whatever else Luther might have been - monster of the medieval midway or prophet of the new age, heretic or reformer, co-father of acquisitive capitalism or herald of freedom - he most certainly was a preacher. He understood himself to have been called by God to be a witness of the gospel of Jesus Christ. Whether holed up in his office for the third straight sleepless night, off on a trade in a lecture, climbing into the pulpit, visiting with friends, or playing with his family, this calling shaped Luther's life.

(Nestingen 1982:27)

Even though he was treated with contempt and rejection, as observed from the labelling he suffered, he stood for what he believed uncompromisingly, as witnessed by Lohse (1986):

Luther, however, was unique in his understanding of God and the devil as directly intervening in historical events. The principle is the same one Luther followed in understanding the meaning of the cross.

(Lohse 1986:194)

Another factor contributing to the plight of the excommunicated is the attention such people draw, which is in itself traumatic. Lilje (1983) spells this out as follows:

The attention of the public was directed towards Martin Luther. Insofar as the news system of the day allowed, the glorious advance of the Wittenberg monk had been followed across Germany.

(Lilje 1983:61)

The author agrees with Lilje (1986), Lohse (1980) and Nestingen (1982) that a person, though rejected directly or indirectly by the ecclesiastical body, should stay focussed on the One who called his or her and should not be swayed, for his or her reward will come from God and not from the church.

\section{Rejection resulting from excommunication}

The one burden any victim of excommunication will have to live with is the sense of rejection. This kind of rejection manifests itself in various forms. Martin Luther was diagnosed as follows: 'Luther's life was deeply marked by the kind of nightmare terror, now sometimes being identified by psychologists as birth or pre-natal trauma' (Yule 1985:52).

Luther became a reformer out of urgent pastoral concern. It was not his first intention to begin a theological revolution; it was certainly not his aim to lead an ecclesial revolt. These steps followed, to be sure, but (as he himself later insisted) they were not yet in view 'when I began that cause'.

(Yule 1985:72)

The originality of Luther's theology is in the way he interwove its anti-Pelagian slant with the central affirmation of the Christian 
faith, that Jesus Christ, though of one nature with God the Father, became our brother man. His whole discussion took on a fresh and personal approach which was often lacking in the later Mediaeval Theologians whose works on this subject often read like a text book on symbolic logic.

(Yule 1985:87)

As I wrote in my treatise against the peasants, so I write now. Let no one take pity on the hardened, obstinate, and blinded peasants who will not listen; let anyone who can and is able, hew down, stab and slay them as one would a mad dog.

(Hyma 1928:76)

The author views Luther's engagement in the Reformation as crucial in protecting the dignity and integrity of the Gospel. He agrees with Luther's pastoral concern that prompted in him the desire to affirm the Christian faith to the extent of demanding the stabbing, slaying and hewing down of those who were hardened and obstinate. Luther propagated these actions out of passion for protecting the Christian values and introduced extremely strict measures of excommunicating these hardened and obstinate people. The pain of the rejection he experienced himself as a result of his doctrinal stance was automatically transferred to the subjects who were meant to be recipients of his message of grace.

The author agrees with Yule (1985) and Hyma (1928) that at the heart of excommunication lies the pain of rejection, the scars of which cannot be eradicated even by the passing of time. The rejection resulting from excommunication, the author believes, equals in all aspects the rejection experienced in incarceration.

It is in the light of these facts that the author believes that the worst that could befall a person is to be buried alive through the rite of an indefinite excommunication, the brutality of which is spelt out by Luther who calls for the stabbing and slaying of the peasants.

The author holds a totally different view from Luther, though, and believes that the victims of rejection, the excommunicated and the hurting, need to be listened to before they are axed or stabbed. This belief is echoed by Wimberly (2003) in the following way:

There is liberation available through talk therapy. But to be effective, therapy needs a mentor who exhibits care and who has the necessary experience to provide the kind of empathy that aids the care seeker to anticipate the future.

(Wimberly 2003:64)

\section{EXCOMUNICATION AS OBSERVED IN THE OLD TESTAMENT}

\section{The Leviticus code}

This set of laws required that a person with leprosy be removed from the community:

This shall be the law of the leper for the day of his cleansing. He shall be brought to the priest, and the priest shall go out of the camp, and the priest shall make an examination.

$(\operatorname{Lv} 14: 2-3)$

\section{The four lepers}

In the Book of Kings there are four men whose encounter is narrated as follows: 'Now there were four men who were lepers at the entrance to the gate; and they said to one another: "Why do we sit here till we die?"' (2 Ki 7:3).

Both instances reflect the isolation and the removal of people infected with leprosy from the community. Isolation was used in the Old Testament as a way of protecting the community from being contaminated by the leper. There was a point, however, when such a person would be restored to the community. In my case the church does not think of any form of restoration. This is the trauma I am referring to.

The church discipline of excommunication is applied for the good of the church and person until such a person is restored. This poses a question in the case of the author's own encounter. The author strongly believes that whatever the cause of his excommunication, this can by no means be beyond the forgiving and restoring blood of Christ Jesus and grace of the Father, the Son and the Holy Ghost.

\section{THE AFRICAN CONCEPT OF EXCOMMUNICATION}

The African concept of excommunication is holistic in that it deals with the totality of the person in relation to his or her environment. It is a concept that contains elements of ubuntu (humanity). This system works with a person until he or she repents, to the point where he or she will be fully restored to the community.

If excommunication is applied unjustly, it may cause the person to react with anger, which may lead to violence, hence the need for an honest medium of empathy and ventilation, regarding which Mbiti (1986:94) states, 'African prayer seems to be very honest, very open, very sensitive to both physical and spiritual aspects of human life.'

The author thinks that the Pentecostal religion is only concerned with what one has to offer and not with the total salvation and restoration of a person, defined by sensitivity to the whole person, as evidenced by the Afro-centric way of praying and the belief system described by Mbiti (1986) above.

Mbiti (1986:229-230) further states, 'So Christians do not theologize first and then pray afterwards. Prayer is a natural aspect of their life, as if there is an inbuilt inclination to pray.'

It becomes evident that an Afro-centric way of dealing with excommunication entails more than disciplining a person but intends to restore a person to unquestionable wholeness. This is further attested by Kourie and Kretzschmar (2000:12): 'Christian spirituality has for many decades been identified with a radical world-denying, anti-materialistic, ascetic philosophy of life.'

The author believes that the ecclesiastical body has to make an admission proposed by Mbiti (1975:52): 'While God has made all things, he himself is not made.

This admission will be therapeutic and create a spirit of acceptance and tolerance when dealing with excommunication.

It also presupposes the sovereignty of God. It is at this stage that the author would love to present the stories of the victims or survivors who were actual recipients of the excommunication ritual. Though the degrees of their hurts differ marginally, the scars and bruises these people sustained bear the same testimony to the impact and effects of trauma.

\section{REAL EXCOMMUNICATION ENCOUNTERS}

First, the theology of Pentecostal churches regarding excommunication is expounded. Whereas the essence of excommunication is about protecting the honour of Christ, in Pentecostal circles or maybe only the one the author as well as his interviewees was exposed to, the victims or survivors of excommunication seem to be at the mercy of the powers that be. These authorities exercise their powers in whichever way serves their best interests. This section will therefore analyse the processes of excommunication in place within Pentecostalism by telling the stories of three victims or survivors. 
In the previous sections the author indicated the theological basis of excommunication in both the Old and New Testament. However, modern Pentecostalism, the variety the author and his interviewees have been exposed to in particular, defines and practises the rite in a totally different manner from the basic biblical precept. In the author's own case he was summarily removed, without any hearing, formality or procedure, hence his resorting to the press.

The author initially planned to interview three ministers from Pentecostal churches. As soon as he started engaging with the three victims or survivors, it became clear that the interviewees were more offended, hurt and broken than they had actually realised, each in his own way. This afforded the author an ample opportunity to listen to their stories with empathy and attempt to visualise the impact and effects of the trauma incurred by the victims or survivors.

Listening to the stories told served as a window through which the author realised how much healing he needed himself. The interviews actually served as a catalyst for the author's own much-desired healing. The stories shared by the victims or survivors of excommunication in this section reveal rather sensitive and emotional information on how people are mere objects of the powers that be, concerning which Neuger (2001) states,

A theology of ownership suggests that humanity was granted dominion over creation by God and that dominion was interpreted to mean ownership. Along with ownership is the tendency to objectify that which is owned so that the needs of the owner are considered primary and the purpose of the owned (or objects) is to serve the needs of the owner.

(Neuger 2001:97)

Such abuse of power and display of ownership lead to feelings of insecurity and defencelessness. According to Kalsched (1998:164), 'One of the healing factors in this working-through period is the fact that this time, the therapeutic "trauma" comes after a period of essential self-object "illusion."'

The author agrees with Neuger (2001) that the misconception of those in authority that they own the flock of God, leaves the vulnerable flock under the illusion spelt out by Kalsched (1998) that the flock is meant to be mere objects. Gerkin 1997:114 warns strongly against this misappropriation of power and authority in the following way: 'The role of the pastoral leadership must more clearly and intentionally than in the recent past develop a quality of interpretive guidance.'

Gerkin (1997:115) further continues to argue, 'Pastors have been taught to think of their ministry as a collection of specialized functions.'

The author believes that if the church leadership can start to consider itself as mere stewards of God's mercies and not as dispensers of judgment and further view each individual as part of the whole, this can serve as a platform of healing and acceptance of others.

\section{Understanding the art of story-telling}

In remembering our own stories and those told us by other members of clergy families, five interrelated themes of challenge consistently appear: the challenge of moving, the challenge of meeting expectations, the challenge of making family life count, the challenge of meaning-making in parsonage living, and managing catastrophic events and other devastating circumstances.

(Wimberly \& Wimberly 2007:20)

It is hoped, therefore, that Africa's genuine believers across the spectrum of faiths will keep radiating an unequivocal message of inner sincerity instead of outward show. It is also to be hoped that such a message, even if it is spread by small numbers of real believers, will have a decisive impact on the supporters of fundamentalism and related extremes of literalism, dogmatism, ceremonialism and traditionalism.

(Malan 1997:66)

The Wimberlys (2007) portray storytelling as helpful in meeting challenges, a notion reinforced by Malan who believes that in such a practice believers of all faiths will be helped to learn to portray inner sincerity as opposed to the outward show. The author agrees with both authorities that there is inherent therapy in dialoguing, which is further reiterated by Malan (1997:93): 'Usually the initial discussions lead the parties into the mode of negotiating, which can be as frank and direct as the discussions.'

It is at the point of admitting that there is a need for discussion that listening to someone share his or her story can be viewed as valuable.

The author supports the above authorities to the extent that he also agrees with Bujo (1992:72): 'In the same way, African theologians too must speak with a prophetic voice. They should not begin by elaborating theories which they themselves do not put into practice.'

This is a clear call to the clergy to be contextually relevant and allow those they are leading to tell their stories while they themselves are prophetic in the execution of their duties, with special emphasis on the African context researched by the author. Ultimately the impact and effects of trauma can be handled in such a manner that identification with the victims or survivors can be sought for effectively.

\section{Story-telling: A pivotal practice}

We want to emphasize here that story-sharing is pivotal to the discovery and ongoing formation of resilient faith through which clergy families discover an unfolding story plot through a vital relationship with God.... For all who embark upon the experience of shared story, it will mean making sense of the stories and envisioning not only what facing forward means, but also what must be done to move forward with the purpose and hope.

(Wimberly \& Wimberly 2007:37)

'The roots of pastoral counselling in many cultures lie in the healing and restorative activities and arts practiced by priesthealers in ancient times' (Lartey 2003:16).

The importance of the resilient faith espoused by the theories of the Wimberlys (2007) will be evidenced later in the stories shared by the interviewees. It is true that the unfolding of the story should be centred on a vital relationship with God. The author supports the notion that is echoed by Lartey (2003), who traces pastoral counselling back to time immemorial when the priest was considered not only as a spiritual leader but as the agent of healing as well.

Story-telling as a practice that seeks to bring about healing should take into account what Gillespie (2000:12) expresses in the following way: 'The foundation for all Christian theology is the revelation of Jesus as attested in scripture.

Anything in the church or anywhere else that is held in higher esteem than the aforementioned biblical requirements quoted by reputable authorities is not only subject to intensive scrutiny but is also bound not to result in the healing addressed in this work and hence tends to be a fallacious superimposition aiming at nullifying the work of Christ on the cross.

\section{Unmasking as a tool for healing}

But, the full nature and depth of these stories may remain submerged or stilled within family members, while at the same time, there is a deep yearning to give personal account of what has happened or is happening, For this reason, unmasking is the first 
practice in the process of story-sharing. Unmasking refers to our allowing internal and unspoken happenings and circumstances of our lives - challenges and promises - to come to life in narrative form. Thus, we may also refer to sharing our stories as 'narrative unmasking'.

(Wimberly \& Wimberly 2002:37-39)

'Radical and systematic approaches focus on changing social systems so that all their members will be freer to grow towards wholeness' (Lartey 2003:86)

The author agrees that in an attempt to seek healing, it is extremely important to unmask past experiences and events. In this way one will be able to reach a place of emotional catharsis, which can serve as a platform for therapy. Lartey (2003) expresses this in a powerful way by conceptualising it as a radical and systematic approach that is capable of producing growth to wholeness.

The Wimberlys (2007:38) further state, 'This story-telling exercise allows us to be creative agents in seeing as assessing our lives and in envisioning God's activity and plan for our lives'.

Finally, we view narrative unmasking as a vital way of renewing our lives and updating the purpose for which God called us as individuals, marital partners, and family members. This is what we call the unmasking of a master story.

(Wimberly \& Wimberly 2007:40)

The author agrees with the belief espoused by the Wimberlys (2007) in their conceptualisation of unmasking. He maintains in the strongest possible sense that everyone does have an original story of his or her own that the whole world has long been waiting to hear. This story is in itself the liberator from future fears and the trauma of the past, an original personal package second to none, the need of which for genuine therapy Rogers (1942) indicates in the following way:

Therapy, it cannot be stressed enough, is not merely being 'nice' to a person in trouble. It is helping that person to gain insight into himself, to adjust to human relationships, with their positive and negative aspects, in a healthy fashion.

(Rogers 1942:105)

This creates a base for potential healing for the hurting, especially the excommunicated. In this condemning world, there is a great need for a platform to unmask the hurts and frustration we daily encounter. One such platform is described by A.E.S Wimberly (2004) as follows:

In addition to baptism, the sacrament of Holy Communion, also called the Lord's Supper or Eucharist, is a highly revered ritual in the life of the black worshiping congregation because of its nurturing effects.... The event became known as the Welcome Table where no one is turned away and where the meal becomes the bread and substance of life or the spiritual food for the journey ahead.

(A.E.S Wimberly 2004:17)

The author agrees with A.E.S Wimberly (2004) that the sacraments such as the Eucharist should serve as a platform on which people can vent their personal frustrations in an environment of safety, better described by Christ in the invitation He extends to everyone: 'Come to Me, all you who labour and are heavy laden, and I will give you rest' (Mt 11:28).

This invitation extended by Christ allows each person to unmask his or her story with the assurance of confidentiality. In his treatment of the subject of privileged conversations with God in the character of Clifford, A.E.S Wimberly (2003) has this to say:

Now all other conversations had to be interpreted by this new, liberation conversation. His transformation healed him when he was able to maintain the privileged position he had given conversation with God, letting this conversation push the old binding ones away. His transformation became healing for others when he began to tell his story letting others see the benefits of being God's beloved child.

(A.E.S Wimberly 2003:23)
This is the attitude the author supports as desirable in the process of unmasking our stories since it provides room not only for confidentiality and transparency but also for transformation and renewal of the true identity and reinstatement of the true self. The author views this as classical rapport.

\section{The mythology}

In unfolding the master story, the Wimberlys (2007) introduce the concept they call 'the mythology' as follows:

... the beliefs and convictions of clergy family members form a mythology that cannot be ignored in the story-telling process. Indeed, the mythology may be a key factor in developing individual and family resilience in the face of challenges.

(Wimberly \& Wimberly 2007:41)

At the centre of the Hebrew story is a God of compassion who suffers with the world to keep it from falling apart. A feeling of dependence on an Order-Of-Things and Beings beyond us and on an Ever-Ordering-Being or Vital Force which led Abraham to walk away from the delta that was gradually getting overpopulated.

(Oduyoye 1986:67)

In reinforcing the foundational truths echoed by the two above authorities, the author would reiterate that it is imperative for anyone to create a mythology of some kind. Be it for families, communities and individuals, as the Wimberlys (2007) point out, or be it for a nation, as pointed out by Oduyoye (1986), the principal factor is all encapsulating. The mythology becomes the driving force, the sustaining activity and lubricant during the most difficult times of our journey. An equivalent expression is employed by A.E.S. Wimberly (2004:117) who states, '... becomes the bread and substance of life or the spiritual food for the journey ahead'.

The Wimberlys (2007:45) regard the family ministry mythology as an often nurturing influence when the family is in crisis, and it functions as a shared story that provides them with perspective and meaning in difficult times. The World Council of Churches (WCC) (1997:24) furthermore states, 'There can be no valuable relationship in which each does not desire the well-being of the other'.

The author agrees with the Wimberlys (2007) that the family mythology is a helpful instrument that can sustain the family when it is going through a crisis. The principle holds equally true for an individual. One can be sustained during the most hurtful moments if one has a mythology to reflect on.

\section{Real stories told}

In this section the author will reveal the stories of three ministers in Pentecostal churches in the Sebokeng area (a township in Gauteng Province, South Africa), which happened to be the geographical territory he researched. They are between the ages of 33 and 45 years. They were all assured anonymity in the recording of their painful encounters.

The interviews were granted voluntarily without any coercion whatsoever. The author explained the background of the study and the importance thereof to the interviewees. He emphatically indicated that the intention of the study was not to throw stones at the church but rather to create an instrument that will be a reference point for Pentecostals when they contemplate disciplining one of their own.

The author chose to use the names of three characters in the Bible as pseudonyms for the three interviewees, the reason being that he regards these men as those

... on whose bodies the fire had no power; the hair of their head was not singed nor were their garments affected, and the smell of fire was not on them.

(Dn 3:27) 
These three men, Shadrach, Meshach and Abed-Nego, had but one immovable testimony: 'Our God whom we serve is able to deliver us from the burning fiery furnace' (Dn 3:17).

The strength of the conviction that sustained the three men who were cast in the furnace is the same that sustained the three interviewees. This is best illustrated by the Wimberlys (2007:41) in their subject of the mythology, an analogy that has become a helpful tool to the author himself.

The format of the interviews, though not fixed, was guided by the following questions to usher the interviewees into the discussion. In each case the author started by sharing his own ordeal and allowed the interviewees to unpack their own stories through the method the Wimberlys (2007:44) describe as relating empathically and unpacking personal stories.

- What actually happened?

- When did it happen?

- How did it affect you?

Your own recommendations (It is important to note at this point that the recommendations made by the interviewees served as building blocks towards the envisaged methodology, instrument and tool the author was attempting to create through this research.)

This was a helpful exercise to discover the extent of the impact and effects of the traumatic encounter that the victims or survivors had to endure.

It was in the stories of others as they were venting their harrowing past that the author was able to stretch out his hand and touch his own long-overdue healing. The process was about more than listening to the stories of others; it was about coming to grips with the reality of what had happened and thus embrace one's own healing.

Due to the lack of a clearly defined theology related to excommunication among Pentecostals, the following accounts were treated with maximum confidentiality by the author:

\section{Story 1}

Shadrach (not real name) unpacked his story as follows:

'I was a very active member of the church, so much so that the Senior Pastor would leave the entire church responsibility with me. This element of trust that had developed between us encouraged me to grow in faith and desire to seek the Lord and learn how I could best serve Him, His servant and the congregation.

'I walked before the Lord and the congregation with integrity, trembling and fear. I was responsible for the finances and administration of the church. Not once was I ever accused of misbehaviour or mismanagement of my duties. I was also responsible for evangelism and very helpful in the arranging of the sound system in the church.

'Everything took a turn for the worse when the elders called for a meeting in the presence of the Senior Pastor and advised that I should no longer help with the sound system since this engagement was degrading me. I was told it would be handled by some junior church members. At this point I was also told the church would buy me all necessary equipment and assist me to set up the evangelism ministry, something which was meant to happen very soon.'

'The same day in the evening someone came to my place and told me that the Senior Pastor wanted to meet with me urgently. Excitedly I left, hoping that I was heading for good news. To my shame and surprise, the Senior Pastor told me that I had to wait and put everything that was discussed in abeyance since he would be going to the USA. He would expect me to be responsible for the church affairs in his absence.'

'However, the Senior Pastor did not go to the USA. The elders even changed the position I used to sit in. I was now positioned right up front, in a more prestigious position. Little did I know that this was where I was going to be getting my answers from. I had asked the Senior 'Pastor a few days earlier about the developments regarding the evangelism ministry since he had not gone to the USA. He did not answer me. I instead got fire and brimstone responses from the pulpit.

'In one of those sermons he said, "Some play important in the church. They need special attention to the extent that they have even relinquished their roles and have assumed important positions in the church. They do this in the name of getting special attention. If you believe to be called of God, why then don't you ask the same God to provide for you and to set you up in what you consider your gifting in the fivefold ministry?"

'In good faith I played deaf to all those horrendous verbal attacks coming from the pulpit. It worried me that the river that was supposed to be gushing waters of life was gushing bitter water. I pursued my cause by requesting an audience with the Senior Pastor and the church elders. The church elders told me that they understood everything but had little or no authority whatsoever to give me the go-ahead. They actually indicated that the Senior Pastor was the only one who could bless my intentions and that I should approach him.'

'Every approach I made towards the Senior Pastor was blocked by his bodyguards, who always told me that he was busy. My one-time confidant, the Senior Pastor, was now miles away and inaccessible. To crown it all, he was tirelessly attacking me from the pulpit, so much so that some of the congregants were starting to question some of the sermons.'

'At this stage I was labelled as a devil worshipper, a label that not only troubled me but so affected me that even in my personal moments of silence I could hear the shout in my ears: devil worshipper. Not only was my integrity affected but my relationship with the other church members was also strained. Some of the people who used to be very close to me, started treating me with serious suspicion, especially now that I was known to be a devil worshipper. Soon, I decided to leave the church in search for peace and true tranquillity. Just a stone's throw from this church, I planted mine.

\section{Story 2}

Meshach (not real name) welcomed the author for an interview that lasted for only three-and-a-half minutes after he had shared his own ordeal. This is how he told his story:

In the year 2001 during a Sunday service, without any form of consultation, the administrator stood up after the church service and announced that "Pastor Meshach will no longer be our pastor, effective from this very moment"'.

To the author's surprise, Meshach said that was all. He refused to continue and fixed his eyes on the television until the author thanked him for his time. He asked him how the congregation responded to that and this served to unblock the impasse that had taken place.

Meshach started opening up and responded as follows:

'This person, the administrator, must have been sent by the Senior Pastor since he was not in the church that day. He arrived just after the service and requested the congregants to heed the announcement. The congregants demanded an explanation but no one gave any. Though there was a constitution in the church, this was not utilised. The charismatic and Pentecostal churches do not observe the constitution. One is suspended or excommunicated at the will of the Senior Pastor and maybe the elders or church council in other instances.'

'The procedure was not available, no counselling was provided and no pastoral care measures were entertained. In the Pentecostal Church when they excommunicate, there are no systems put in place for restoration. It is practically like people enjoy excommunicating others.' 
'They will just excommunicate you and not check what happens thereafter. Excommunication is seen as such as a licence to send the culprit to hell. Maybe it is because people do not understand the reasons for excommunication. The discipline exercised is more punishing than disciplining with the intention to restore the offender. It should be noted that the excommunicated person is a candidate for repentance. I think discipline should be about the maintenance of both the integrity and purity of the church. It is currently done haphazardly.

'In my case the Senior Pastor must have felt threatened, apparently by my leadership gifting. We as Africans do not observe unity in diversity. Some important facts to note are the following:

- We should know the reasons for excommunication.

- Unity in diversity should be observed in the church.

- Different gifts should not threaten anyone.

- Concepts of understanding the ministry are important and should be known.

- In conclusion, we should learn to work together in tolerance.'

'Ministry should be understood to be about God. Pastors do not work together because people are working to build their own kingdoms and not God's kingdom.'

'In my case excommunication was a blessing in disguise. Other people will fight you if you are blessed in their midst. Excommunication can have a positive side too, namely:

- The building of character.

- Separating you from other people so that God can bless you apart from them; that is why God said to Abraham, "Leave your own people."'

'I took it positively, hence my success in the present ministry that I started not very far from where I was excommunicated without a reason.'

"Isaac Newton said, "It was in standing on the shoulders of giants that I could see the future." Today I am feeding 300 orphans, victims of HIV/AIDS, I am running HIV support groups and I have three qualified social workers and a nurse fully available in the service of the church.

'If you do not want to leave when God indicates that you should leave, rest assured that He Himself will push you out."

\section{Story 3}

Abed-Nego (not real name) told his story as follows:

'In 1999 I submitted a letter to the Church Council and the Senior Pastor requesting to be released from active pastoral work as I was one of the assistant pastors. This was as a result of the perceived fears, stress and pressure I was going through. I was released and went to join another church. A month later I decided to come back and informed the Church Council and the Senior Pastor. I requested to be active again.'

I was called in and asked what had actually made me require being passive at first and why I had changed my mind about my initial decision. One of the painful experiences I had was when one of the Council members asked me how I would feel to be called an ordinary member and no longer a pastor. I told him I had no problem with that. He must have been angered by the fact that I could not be provoked. Little did I know that the worst was still to come. He bashed me with a question I never expected: He asked whether I was HIV positive in full view of all the Council members.'

'This must have been the cause of the depression I had suffered in the process of what I was going through. Then they told me that the Senior Pastor had decided to excommunicate me in his personal capacity until he was satisfied. No reference was made to the constitution, nor was it actually used to execute the sentence on me.

'This indefinite excommunication lasted for two years, in other words "until the Senior Pastor was satisfied". I was attending the church as a regular church member even though the Lord would use me in an extraordinary way outside the church where my services were required and valued.
'After two years of passivity, I was called by the Church Council and the Senior Pastor. They told me that on a certain day I should be available at church. I obliged and on this particular day they announced that they had tried all they could to make "it hard for me". The meaning of this phrase was not explained to me. They further affirmed that I had proven that I am really called of God. As the church and the leadership of the church, they respected me. I was restored by public declaration. Since then it has become extremely difficult for me to hold any active position in the church. I have been one of the pastors without portfolio for a period of 10 years this day.

'I am still passive by personal choice. God is using me outside the church where people value my services. But on Sundays if there is no outside invitation, I do attend church. Whenever the Senior Pastor assigns me to assist with the crusades in the branches, I will carry out the task with pleasure. Should he require me to conduct a funeral or render any other service, I gladly assume the duty. Whenever my services are required at church, I serve with commitment and humility.'

These encounters led the author to the following conclusions:

- Excommunication has no healing effects in Pentecostal circles whereas the Gospel of Jesus Christ advocates restoration.

- Restoration as portrayed in the pastoral care theology advocated by Gerkin is lacking in Pentecostalism.

- Jesus Christ restored Peter in fullness and even entrusted him with the task to tend His sheep (Jn 20:16).

\section{Lessons from the real-life stories}

As the victims or survivors shared their stories, the author was taken back to a point in time when he had a similar encounter. The scars and the marks are as bright as though they happened yesterday. He was stirred in his spirit to seek for a deeper and more meaningful way of relating to the realities of his own nightmares. With empathy, the author identified with the victims/survivors as he recalled the stripes that Christ bore for the sole purpose of healing the impact and effects of trauma.

Brown (1992) explains how Niebuhr found solace in the following statement:

Despite a stroke in 1952 that slowed his pace, he made a two-thirds comeback and did some of his best work, journalistic and reflective, during the placid 1950s and the stirring 1960s. He produced more books that elaborated, complemented, and refined themes of theology and social philosophy set forth in the 1940s.

(Brown 1992:7)

Freedom of conscience has reference not simply to the constitution of ecclesiastical bodies but also to the unofficial 'laws of society,' or what is called political correctness. Christian conscience is bound to God and not to the ideologies of a society.

(Leith 1993:205)

All the interviewees indicated that the constitution of the church was overlooked, not considered or not even available in some instances. This proves beyond any shadow of a doubt that what Leith points out is very true, namely that freedom of conscience has reference not only to the constitution of the church but also to unofficial unwritten laws. It is this reality that the author supports. He believes that if one can square one's shoulders and define one's own role and purpose in life, there is bound not to be unnecessary squabbles in ecclesiastical gatherings. Instead, people will leave with an ever-refreshing feeling of hope, like Niebuhr who was renewed when there seemed to have been no hope in his state of affairs.

As a result of the impact and effects of trauma resulting from excommunication, the victims or survivors tend to resort to the following behavioural mechanisms: 


\section{Withdrawal}

There are invaluable lessons Herman (1997:133) points out regarding the behaviour displaying itself through withdrawal. He draws the following picture: 'The core experiences of psychological trauma are disempowerment and disconnection from others.'

It is evident from the above that in psychological trauma there is not only the disempowerment aspect but there is also a very critical element known as disconnection from others. The author aligns himself with this call for a more sensitive pastoral approach when dealing with victims or survivors of excommunication. This need is best illustrated by Wimberly (1999:7): 'Pastoral counselling embraces a more non judgmental and accepting attitude while preaching embraces a more moral perspective in which people are challenged to change their attitudes.'

It is in the spirit of false acceptance of their own plight that people such as Abed-Nego are not only disempowered but also disconnected from others. This is verified by his confession that he has chosen to be passive in church affairs for a period of 10 years. This disconnection manifests itself through the yielding he is displaying by believing that it is the meekest, the most appropriate and humble conduct to be passive in the church.

The author agrees with Wimberly (1999) in this regard that the kind of pastoral care required is one that will embrace a more non-judgemental approach so that the victims or survivors of excommunication will feel both welcome and challenged to change his or her attitude and live a life connected to others.

\section{Sense of guilt}

As a result of the difficulty of the excommunication encounter, one is bound to internalise a sense of guilt. In addressing the subject of the human nature and destiny, Brown (1992) states,

The Christian understanding of human nature, Niebuhr pointed out, appreciates the unity of body and soul as part of the goodness of creation. It further regards the human person as made in the 'Image of God.'

(Brown 1992:9)

It is in the internalisation of a sense of guilt that one will be tempted to overlook the reality of the completeness with which one is created, namely the image of God, against which there is no gainsaying, including a sense of guilt.

In support of his intention to pursue the course of caring, Browning (1996:98) states the following: 'It was from the beginning a concern to relate theology and social sciences to inform caring practices in concrete situations.'

In buttressing the trend of thought advocated by Browning (1996), the author strongly supports the notion of an informed minister, hence the great need to educate the clergy about the importance of synthesising theology with other disciplines of the social sciences. An informed clergy will at least know the basics of administration, such as reference both to Scripture and the guiding document of the organisation, in other words their own church constitution.

With this knowledge will also come sensitivity in dealing with those deserving of sanction such as excommunication. The primary objective of excommunication will as such fulfil what Browning (1996) addresses in the subject of human nature. Although excommunication is not a desirable course of action, the ultimate redemptive aim of restoring the beauty of the image of God in humanity will be appreciated by the victims or survivors once this practice is carried out in a more responsible and informed manner, as alluded to by the above authorities.

The author further agrees that a sense of guilt is not natural. These are hurtful feelings resulting from the imposition of circumstances.

\section{Extra-cautiousness/-carefulness}

There is an English proverb that says, 'Once bitten, twice shy.' The implications are that once one has become the prey of circumstances beyond one's control or a victim of an unfortunate situation, an extra measure of caution is likely to be exercised in all future similar circumstances.

On this subject A.E.S. Wimberly (2005), initially speaking on account of the youth, says the following:

Given the current context of marketing forces affecting the lives of our black youth, and the relative impotence of the church to respond, black youth are left floundering without compass or rudder.

(A.E.S. Wimberly 2005:43)

In support of A.E.S. Wimberly (2005) view on the forces that affect the youth, the author would love to agree that a vacuum exists in the Pentecostal Church, reflecting the lack of a rudder, so much so that the church seems to live in the commercial world of co modification, addressed at length by A.E.S. Wimberly (2005:42-43). This floundering in which the church is left due to the state of ignorance gives birth to the very fear inherent in the above-quoted proverb, whereby one would be prompted to exercise extra caution in whatever one does henceforth.

According to Brown (1992:75), 'The law of human nature is love, a harmonious relation of lives in obedience to God.'

The author affirms the truth upheld by Brown to the effect that whereas it is a healthy practice to be cautious, extra-cautiousness or -carefulness tends to be more of an ailment or abnormality than normal conduct. This affects and destabilises the leading of a life in obedience to God. One will automatically start to live one's life in abject fear of an unpredictable future, hence affecting the harmony that should exist in life.

To this end, Oden (2007) proposes a position that should rather be pursued by the church:

Early African believers gave a lasting gift to world Christianity. The gift was not given without blood and torture. When the evidence is rightly digested, which has not yet occurred, it will again reshape modern African Christian identity and motivation.

(Oden 2007:124)

The author endorses Oden's (2007) opinion that as a way of resuscitating the belief the early African martyrs upheld, it is incumbent upon those who would love to stand for the truth to commit themselves to such uncompromisingly, fully knowing that like our forebears, there is a price of blood and torture to bear. It is in this knowledge and these practices that extracautiousness or -carefulness will be exercised with the joy of discipleship and boldness.

There is therefore no need to live one's life in guilt, withdrawal and self-condemning extra-cautiousness. In the words of Paul, this truth is reflected as follows: 'There is therefore now no condemnation for those who are in Christ Jesus, who do not walk according to the flesh, but according to the Spirit' (Rm 8:1).

This scripture clearly shows that the spiritual home and environment should serve as a place of solace, a shelter for the homeless and a fortress for the destitute and not as an abattoir and should enable the victims or survivors of excommunication to recover from the effects and impact of the resultant trauma.

The world has countless abattoirs in various forms, shapes and sizes. The church should be a place where all and sundry can come and enjoy not only fellowship but also the flow of healing grace she has been bestowed with. The Psalmist draws the following picture of such companionship anticipated from an ecclesiastical gathering: 'Behold, how good and how pleasant it is for brethren to dwell together in unity!' (Ps 133:1). 
The author believes that the brutality of the effects of trauma needs even more intense attention now than ever before. This consideration can serve as a platform of healing for the individual victims or survivors of excommunication, the church organisations they belong too and their own equally hurt family members.

\section{CONCLUSION}

The author elaborated on the impact and effects of trauma resulting from excommunication in this article. He analysed a few biblical eras, namely the time of the prophets in the Old Testament, the Pauline era and Christ's era during His earthly ministry in the New Testament, and the Reformation era, under Martin Luther in particular. He looked at the agility and courage Martin Luther displayed against the powers and authorities of his era. He engaged scholastic approaches in the subject of trauma and its effects on the behavioural patterns of the victim/ survivor.

The term pastoral is considerably more than an adjective referring to the clergy. Although in the various Christian traditions there have been a number of meanings for the term, most of those meanings have involved either a pastoral 'attitude' or pastoral 'accountability'. The pastoral attitude, perspective, or way of looking at things has most often been interpreted through the use of the biblical image of the shepherd.... Thus when the term pastoral is used in some contexts it inevitably means an attitude of care and concern.

(Patton 1990:64-65)

The author believes that every single person who goes through the test and trial of excommunication actually shakes the mountain where Christ was crucified once again. The author looked at real encounters with excommunication. He journeyed through real-life stories, employing the Wimberlys (2007) art of story-telling, about which they say the following:

As part of sharing stories of our lives as clergy family members, it is important to create a safe space within which persons can experience catharsis. Cathartic moments are occasions when we feel freed to unburden ourselves by 'telling it like it is'.

(Wimberly \& Wimberly 2007:43)

The author shares the belief of the Wimberlys (2007) that the telling of the story should not be sanctioned by any external stimuli if it is to have the desired therapeutic results. This has been proven to be true with the interviewees who shared their moments of undiluted pain as they expressed the effects and the impact of trauma resulting from excommunication.

The crux of the matter was reached when real stories were shared. These were emotional moments, bearing real-time lessons. They left indelible marks and brought back to life the experience the author once went through while at the same time they served as what Kalsched (1998) describes as follows:

Archetypal defences, then, allow for survival at the expense of individuation. They assure the survival of the person, but at the expense of personality development.

(Kalsched 1998:38)

This behaviour was noticed very clearly in the life of Abed-Nego, who lived in denial of the reality that he was actually hurting, hence his withdrawal from all church activities except when his services were invited. This is a clear indication of the survival of the person at the expense of personality development, as pointed out by Kalsched above.

There is therefore a burden resting upon the Pentecostal movement to revisit its method of excommunication since the current practice seems to be doing more harm than good. The effects and the impact of trauma currently experienced by the victims or survivors of excommunication cannot be adequately described in any terms.

The lesson that needs to be learnt by all those who call upon the name of the Lord, including Pentecostals, is described by Gerkin (1997) in the following way:
More than any other image, we need to have written on our hearts the image most clearly and powerfully given to us by Jesus, of the pastor as the shepherd of the flock of Christ. Admittedly, this image originated in a time and place in which the shepherd was a common-place figure, and we live in a social situation in which shepherding is as scarcely known, even marginalized vocation.

(Gerkin 1997:80)

The author strongly supports the notion of the pastor as a shepherd upheld by both Gerkin (1997) and Patton (1990). This concept and practice provide the desired healing when the impact of trauma cannot be addressed in any other possible human way.

This article went on to discuss story-telling as a pivotal practice. Unmasking was introduced as a way of venting hidden hurts. The concept of the mythology that every individual and family need to have was discussed at length. It emerged in the strongest terms, finally, that the effects and impact of trauma leave an indelible mark on individuals.

\section{REFERENCES}

Allen, D.E., 1974, Conversation analysis: The sociology of talk, Mouton, The Hague.

Atkinson, J., 1983, Martin Luther: Prophet to the church catholic, The Paternoster Press, Devon.

Brown, C.C., 1992, Niebuhr and his age: Reinhold Nieburh's prophetic role in the twentieth century, Trinity Press International, Philadelphia.

Browning, D.S., 1996, A fundamental practical theology: Descriptive and strategic proposals, Fortress Press Assen/Maastricht, Van Gorcum, Minneapolis.

Bujo, B., 1992, African theology in its social context, Benezet Bujo, transl. J. O'Donohue, Orbis, Maryknoll.

Estardt, K., 1983, Pastoral counselling, Prentice-Hall Inc., New Jersey.

Freud, S., 1939, Moses and monotheism, The Garden City Press Limited, Letchworth.

Gerkin, C.V., 1997, An introduction to pastoral care, Abingdon Press, Nashville.

Gillespie, A., 2002, Becoming other: From social interaction to selfReflection, The John Hopkins University Press, Baltimore.

Guralnik, D.B., 1973, Webster's new world dictionary, The World Publishing Company, New York.

Herman, J.L., 1997, Trauma and recovery, Perseus Books Group, New York

Herman, N.R., 1997, The Gospel according to John: A theological commentary, Eerdmans, Grand Rapids.

Hyma, A., 1928, Luther's theological development from Erfurt to Augsburg, F.S Crofts \& Co., New York.

Kalsched, D., 1998, The inner world of trauma, Routledge, London.

Kourie, C. \& Kretzschmar, L., 2000, Christian spirituality in South Africa, Cluster Publications, Pietermaritzburg.

Lartey, Y.E., 2003, In living colour: An intercultural approach to pastoral care and counselling, Jessica Kingsley, London.

Leith, J.H., 1993, Basic Christian doctrine, Westminster, Louisville.

Lilje, H., 1983, Martin Luther, Inter Nationes, Bonn.

Lohse, B., 1986, Martin Luther: An introduction to his life and work, Fortress Press, Philadelphia.

Malan, J.C., 1997, Conflict resolution wisdom from Africa, ACCORD, Durban.

Mbiti, J.S., 1986, Bible and theology in African Christianity, Oxford University Press, Nairobi.

Mbiti, J.S., 1975, Introduction to African religion, Heinemann, London.

Mills, M.E., 2007, Alterity, pain, and suffering in Isaiah, Jeremiah and Ezekiel, Biddles Ltd, Norfolk.

Neethling, K., 2002, Feel like Jesus: Seven guidelines for emotional health, Carpe Diem, Vanderbijlpark.

Nestingen, J.A., 1982, Martin Luther: His life and teachings, Fortress Press, Philadephia.

Neuger, C.C., 2001, Counselling women: A narrative pastoral approach, Fortress Press, Minneapolis. 
Oden, T.C., 2007, How Africa shaped the Christian mind, InterVarsity Press, Downers Grove.

Oduyoye, M.A., 1986, Hearing and knowing: Theological reflections on Christianity in Africa, Orbis Books, London, Geoffrey Chapman, Maryknoll.

Patton, J., 1990, From ministry to theology: Pastoral action reflection, Abingdon Press, Nashville.

Pieterse, H.J.C., 2004, Preaching in a context of poverty, Unisa Press, Pretoria.

Pollard, N., 1997, Evangelism made slightly less difficult, InterVarsity Press, England.

Rogers, C.R., 1942, Counseling and psychotherapy: Newer concepts in practice, Houghton Mifflin, Boston.

Sipe, A.W.R. \& Rowe, C.J., 1984, Psychiatry, ministry \& pastoral counselling, The Liturgical Press, Minnesota.

Trigg, J.D., 1994, Baptism in the theology of Martin Luther, Koln, New York.
Waruta, D.W. \& Kinoti, H.W., 2005, Pastoral care in African Christianity, Acton Publishers, Nairobi.

Wimberly, A.E.S., 2004, Nurturing faith and hope, The Pilgrim Press, Cleveland.

Wimberly, A.E.S., 2005, Keep It real, Working with Today's Black Youth, Abingdon Press, Nashville.

Wimberly, E.P., 1999, Moving from shame to self-worth: Preaching and pastoral care, Abingdon Press, Nashville.

Wimberly, E.P., 2003, Claiming God reclaiming dignity, Abingdon Press, Nashville.

Wimberly, A.E.S \& Wimberley E.P., 2007, The Winds of Promise, Building and Maintaining Strong Clergy families, Discipleship Resources, Nashville.

World Council of Churches (WCC), 1997, Facing AIDS, study document, WWC Publications, Geneva.

Yule, G., 1985, Luther Theologian for Catholics and Protestants, T \& T. Clark Ltd, Eidenburgh. 